\title{
ЛОКАЛЬНИЙ ЕЛЕКТРОМЕХАНІЧНИЙ ВІДГУК ТОНКИХ ПЛІВОК НАПІВПРОВІДНИКІВ-ІОНІКІВ
}

\author{
Г.М. МОРОЗОВСЬКА, Г.С. СВЕЧНІКОВ, К.В. ДЕРКАЧ
}

УДК 538.956,

538.91-405:537.226

(C) 2011
Інститут фізики напівпровідників ім. В.Є. Лашкарьова НАН України

(Просп. Науки, 41, Киӥв 03028)

\begin{abstract}
Проведено розрахунки локального електромеханічного відгуку тонких плівок напівпровідників-іоніків, викликаного локальними змінами концентрації іонів (стехіометричний внесок) та вільних електронів і дірок (електрон-фононна взаємодія внаслідок деформащійного потенціалу). Отримано динамічні деформаційно-вольтові петлі гістерезису в тонкій плівці іоніканапівпровідника з рухливими акцепторами (донорами) і дірками (електронами).

У випадку "блокуючих" електродів, які не пропускають іони, зміни концентрації дірок (електронів) вносять основний внесок у залежність механічного зміщення поверхні плівки від електричної напруги, прикладеної до зонда, що безпосередньо реєструється методами скануючої зондової мікроскопії (C3M). Таким чином, С3М переміщення поверхні іоніка-напівпровідника може надати важливу інформацію про локальні зміни зарядового стану акцепторів (донорів) та електрон-фононні кореляції через деформаційний потенціал.
\end{abstract}

\section{1. Вступ}

Сучасні досягнення інформаційних технологій залежать від швидкісних і високоємнісних пристроїв енергонезалежної пам'яті. Нині інтенсивно досліджуються різноманітні альтернативи сучасним пристроям пам'яті з метою отримання більш потужних і функціональних систем [1]. Однією $з$ перспективних концепцій є концепція резистивної пам'яті [2], що грунтується на напівпровідниках із мішаним типом провідності, наприклад, іонно-електронним [3, 4]. У тонких плівках, що використовуються в комірках резистивної пам'яті, принципово важливою є електроміграція та дифузія іонів.

Інтерес до теорії впливу дифузіі та електроміграції на механічні властивості іоніків-напівпровідників є не лише фундаментальним, але має важливе значення для оптимізації їх електрофізичних властивостей, корисних для застосувань [1]. Тому значний інтерес становлять резистивні матеріали, такі як корельовані оксиди $\mathrm{La}_{1-x} \mathrm{Sr}_{x} \mathrm{Co}_{y} \mathrm{Fe}_{1-y} \mathrm{O}_{3-\delta}, \mathrm{La}_{0,6} \mathrm{Sr}_{0,4} \mathrm{Co}_{0,2} \mathrm{Fe}_{0,8} \mathrm{O}_{3-\delta}$,
$\mathrm{La}_{1-x} \mathrm{Sr}_{x} \mathrm{CoO}_{3-\delta}, \operatorname{Sr}\left(\mathrm{Fe}_{x} \mathrm{Ti}_{1-x}\right) \mathrm{O}_{3-\delta}$, що мають особливі електрофізичні характеристики [5-7].

Вимірювання локальних механічних зміщень поверхні плівок іоніків може надати важливу інформацію про дифузію й міграцію електронів та іонів (акцепторів, донорів), локальні рівні окислення, електронфононну взаємодію через деформаційний потенціал [8] і навіть деформації Яна-Теллера у плівках корельованих оксидів [9-11].

Локальний електромеханічний відгук - локальна деформація поверхні плівки іоніка, викликана дифузією та електроміграцією носіїв заряду (іонів, вакансій, електронів, дірок) під дією неоднорідного електричного поля зонда СЗМ. Локальне зміщення поверхні плівки реєструється апаратурою СЗМ (див. рис. 1).

Коли зондовий електрод і підкладка є блокуючими для іонів, зміна концентрації електронів та дірок через електрон-фононний зв'язок приводить до механічного зсуву поверхні плівки, який викликаний електричною напругою, прикладеною до С3М $[12,13]$. Константа зв'язку пропорційна деформаційному потенціалу, який, в свою чергу, може бути підсилений локальними деформаціями Яна-Теллера, що існують в корельованих оксидах. Це дозволяе пов'язати електромеханічний відгук з локальним деформаційним потенціалом іоніків типу корельованих оксидів $[12,13]$.

\section{2. Мотивація роботи}

Всеохоплююча аналітична теорія електроміграції і дифузії носіїв заряду в іоніках-напівпровідниках та ix тонких плівках є складною та остаточно нерозв'язаною задачею $[1-4,14]$. Зокрема, вольт-амперні характеристики було проаналізовано загалом чисельно, і тільки в рамках наближення Больцмана для хімічного потенціалу та/або лінійної теорії екранування Дебая в наближенні сталої провідності, незалежної від концентрації частинок $[3,4,15-$ 

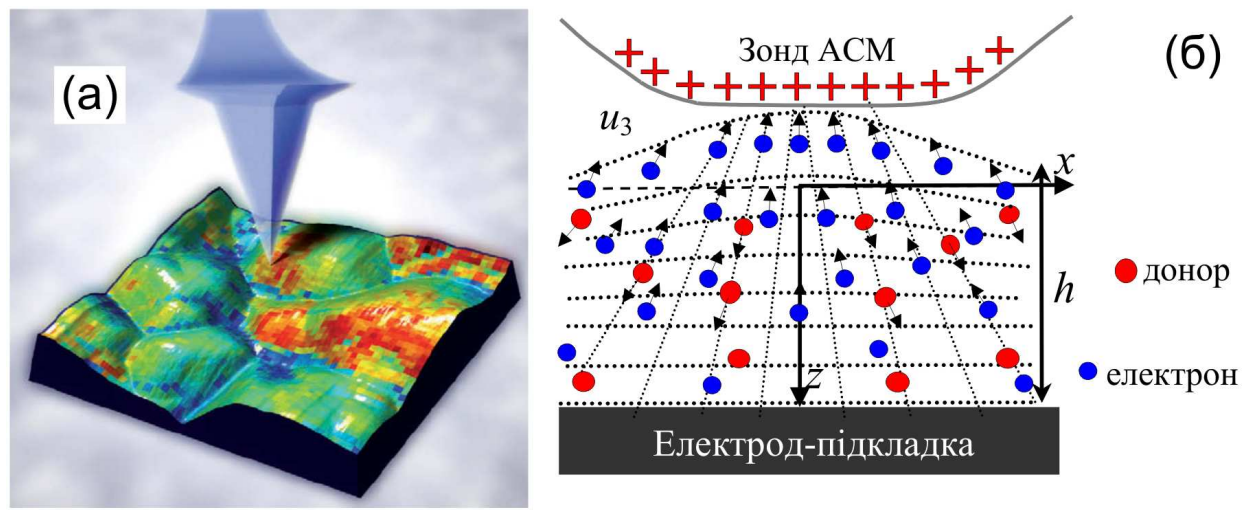

Електрод-підкладка
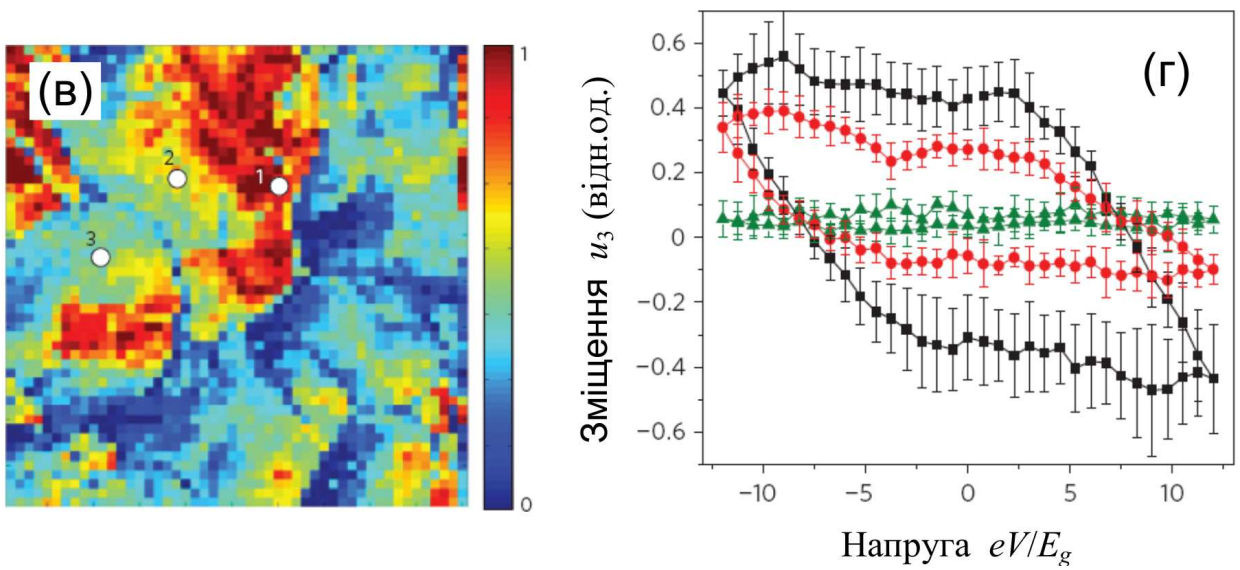

Рис. 1. Схема вимірювання локального електромеханічного відгуку іоніка за допомогою зонда С3М: $a$ - [11]; 6 - [13]. Результати експерименту для плівки $\mathrm{LiCoO}_{2}$ : карти амплітуди локального електромеханічного відгуку С3М (в) та (г) петлі гістерезису локального електромеханічного відгуку іоніка, виміряні в різних точках карти (в) [11]

18]. Ці наближення та припущення не є справедливими в областях накопичення просторового заряду, які зазвичай з'являються поблизу поверхонь та інтерфейсів плівки іоніка-напівпровідника [19-21]. При розгляді іоніків неприпустимо нехтувати електроміграцією іонів, а також мобільністю акцепторів (донорів) та власною шириною домішкової зони [21].

Виникнення деформації поверхні плівки під час електроміграції іонів та/або перезарядки, як правило, не розглядається теоретично $[12,13]$. Деформаційний ефект дуже важливий для роботи сучасних іонних матеріалів для акумулювання енергії і пристроїв пам'яті. Однак у більшості робіт, присвячених цій проблемі, шари просторового заряду, утворені під час дифузії іонів, та виникнення електричних полів ігноруються, тоді як більшість зусиль зосереджено на розгляді неплоскої геометрії, яка робить задачу дуже складною.

3 наведеної літератури можна зробити висновки про те, що:
1. Вольт-амперні характеристики іоніків-напівпровідників і їх тонких плівок були теоретично проаналізовані переважно чисельно в наближенні Больцмана в лінійній дрейф-дифузійній теорії.

2. Теоретичного опису локального електромеханічного відгуку іоніків-напівпровідників, що вимірюється методами СЗМ, не було розроблено.

Ці факти й вмотивували наші теоретичні дослідження. У роботі проведено розрахунки локального електромеханічного відгуку плівки іоніканапівпровідника з енергетичною густиною станів, типовою для корельованих оксидів з рухливими акцепторами, донорами, електронами і дірками. Проведено порівняння з результатами, розрахованими в наближенні Больцмана.

Мета роботи - провести аналітичні та чисельні розрахунки локального електромеханічного відгуку іонік-напівпровідникової плівки з заданою густиною станів з рухливими акцепторами, донорами, електронами і дірками. Порівняти отримані результати з результатами, отриманими в наближенні Больцмана. 


\section{3. Постановка задачі та методи розв'язку}

Теоретичні розрахунки проводили у межах класичної теорії напівпровідників та електродинаміки, механіки суцільного середовища.

Розв'язували рівняння Максвелла у квазістатичному наближенні для електричного потенціалу $\varphi$ плівки іоніка-напівпровідника з рухомими іонами (акцепторами або донорами), електронами та дірками:

$\Delta \varphi(\mathbf{r}, t)=$

$=-\frac{e}{\varepsilon_{0} \varepsilon}\left(N_{d}^{+}(\mathbf{r}, t)-N_{a}^{-}(\mathbf{r}, t)+p(\mathbf{r}, t)-n(\mathbf{r}, t)\right)$,

де $e$ - елементарний заряд, $\varepsilon$ - статична діелектрична сприйнятливість іоніка-напівпровідника, $\varepsilon_{0}$ - універсальна діелектрична стала, $n(\zeta)=\int_{-\infty}^{\infty} d \varepsilon g_{n}(\varepsilon) f\left(\varepsilon-\zeta+\Xi_{i j}^{C} u_{i j}\right) \quad-$ концентрація електронів у зоні провідності; $p(\zeta)=\int_{-\infty}^{\infty} d \varepsilon g_{p}(\varepsilon) f\left(\zeta-\Xi_{i j}^{V} u_{i j}-\varepsilon\right) \quad$ - концентрація дірок у валентній зоні; $\Xi_{i j}^{C, V}$ - деформаційний потенціал електронів та дірок відповідно $[22,23]$. $N_{d}^{+}(\zeta)=\int_{-\infty}^{\infty} d \varepsilon g_{d}(\varepsilon) f(\zeta-\varepsilon)-$ концентрація іонізованих донорів; $N_{a}^{-}(\zeta)=\int_{-\infty}^{\infty} d \varepsilon g_{a}(\varepsilon) f(\varepsilon-\zeta)$ - концентрація негативно заряджених акцепторів. Функція $f(x)=\frac{1}{1+\exp \left(x / k_{\mathrm{B}} T\right)} \in$ функцією розподілу Фермі-Дірака. Електрохімічний потенціал $\zeta(z)=\mu+e \varphi(z)$ визначає рівноважну концентрацію носіїв заряду залежно від відстані $\mathbf{r}$ до поверхні плівки.

Рівноважну енергетичну густину станів носіїв заряду, $g\left(\varepsilon, E_{m}, \delta E_{m}\right)$, задавали у вигляді локалізованих розподілів із шириною $\delta E_{m}$ з різними показниками $k>1$, що є характерною для сильно легованих напівпровідників [5]:

$g\left(\varepsilon, E_{m}, \delta E_{m}\right)=g_{m} \exp \left(-\frac{\left|E_{m}-\varepsilon\right|^{k}}{\delta E_{m}^{k}}\right)$.

У рівнянні (2): $g_{m}$ - стала, індекс $m=a, d, n, p$ позначає акцептори, донори, електрони або дірки. Показник $k>1$. Також замість рівняння (2) для порівняння та для з'ясування ступеня виродження електронів або дірок використано больцманівське наближення, $g\left(\varepsilon, E_{m}, \delta E_{m}\right) \sim g_{m} \exp \left(-\frac{E_{m}-\varepsilon}{k_{\mathrm{B}} T}\right)$.

Крайові умови до рівняння (1) відповідали геометрії та властивостям електродів:

$\varphi(\rho, z=0, t)=V_{0}(\rho) \exp (i \omega t), \quad \omega(z=h, \rho)=0$, де $h$ - товщина плівки, $V_{0}(\rho) \exp (i \omega t)$ - періодичний розподіл потенціалу, що створений зондом СЗМ (див. рис. 2).

Кінетику носіїв заряду розраховано 3 рівнянь неперервності без урахування процесів генераціїрекомбінації "гарячих" носіїв:

$\frac{\partial N_{d}^{+}}{\partial t}+\frac{1}{e} \operatorname{div} \mathbf{J}_{d}=0, \quad-\frac{\partial N_{a}^{-}}{\partial t}+\frac{1}{e} \operatorname{div} \mathbf{J}_{a}=0$

$\frac{\partial p}{\partial t}+\frac{1}{e} \operatorname{div} \mathbf{J}_{p}=0, \quad-\frac{\partial n}{\partial t}+\frac{1}{e} \operatorname{div} \mathbf{J}_{n}=0$.

Струми іонів та електронів вважали пропорційними до градієнтів їх електрохімічних потенціалів $\zeta_{a, d}(\mathbf{r})$ та квазірівнів Фермі $\zeta_{p, n}(\mathbf{r})$ :

$\mathbf{J}_{p}=-e \eta_{p} p \operatorname{grad} \zeta_{p}$,

$-\zeta_{p}(\mathbf{r}) \approx+e \varphi(\mathbf{r})+k_{\mathrm{B}} T \ln \left(\frac{p(\mathbf{r})}{p_{0}}\right)$,

$\mathbf{J}_{n}=e \eta_{n} n \operatorname{grad} \zeta_{n}$,

$\zeta_{n}(\mathbf{r}) \approx-e \varphi(\mathbf{r})+k_{\mathrm{B}} T \ln \left(\frac{n(\mathbf{r})}{n_{0}}\right)$

$\mathbf{J}_{a}=e \eta_{a} N_{a}^{-} \operatorname{grad} \zeta_{a}$,

$\zeta_{a}(\mathbf{r})=-e \varphi(\mathbf{r})-k_{\mathrm{B}} T \ln \left(\frac{N_{a}-N_{a}^{-}(\mathbf{r})}{N_{a}^{-}(\mathbf{r})}\right)$,

$\mathbf{J}_{d}=-e \eta_{d} N_{d}^{+} \operatorname{grad} \zeta_{d}$

$-\zeta_{d}(\mathbf{r})=e \varphi(\mathbf{r})-k_{\mathrm{B}} T \ln \left(\frac{N_{d}-N_{d}^{+}(\mathbf{r})}{N_{d}^{+}(\mathbf{r})}\right)$,

$\eta_{m}$ - рухливість носіїв. Наближені рівності в рівняннях (5a), (5b) відповідають наближенню Больцмана. Окремо розглянуто наближення лінійної дрейфдифузійної теорії.

Крайові умови для струмів на поверхні плівки розглядалися у двох граничних випадках умов ЧангаЯффе [24] для електродів, що є блокуючими та пропускаючими для різних носіїв заряду. Електроди здебільшого вважалися блокуючими для іонів (або вакансій), тобто:

$J_{d, a}^{z}(\rho, z=0, t)=0, \quad J_{a, d}^{z}(\rho, z=h, t)=0$, 


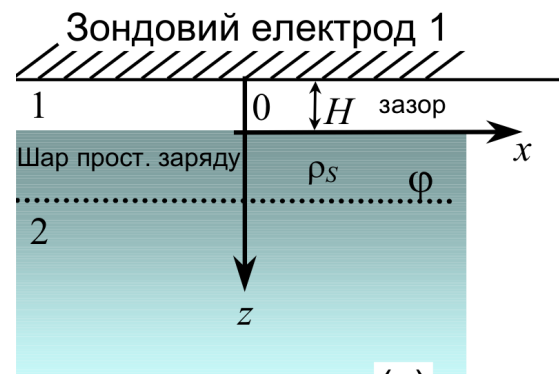

(a)
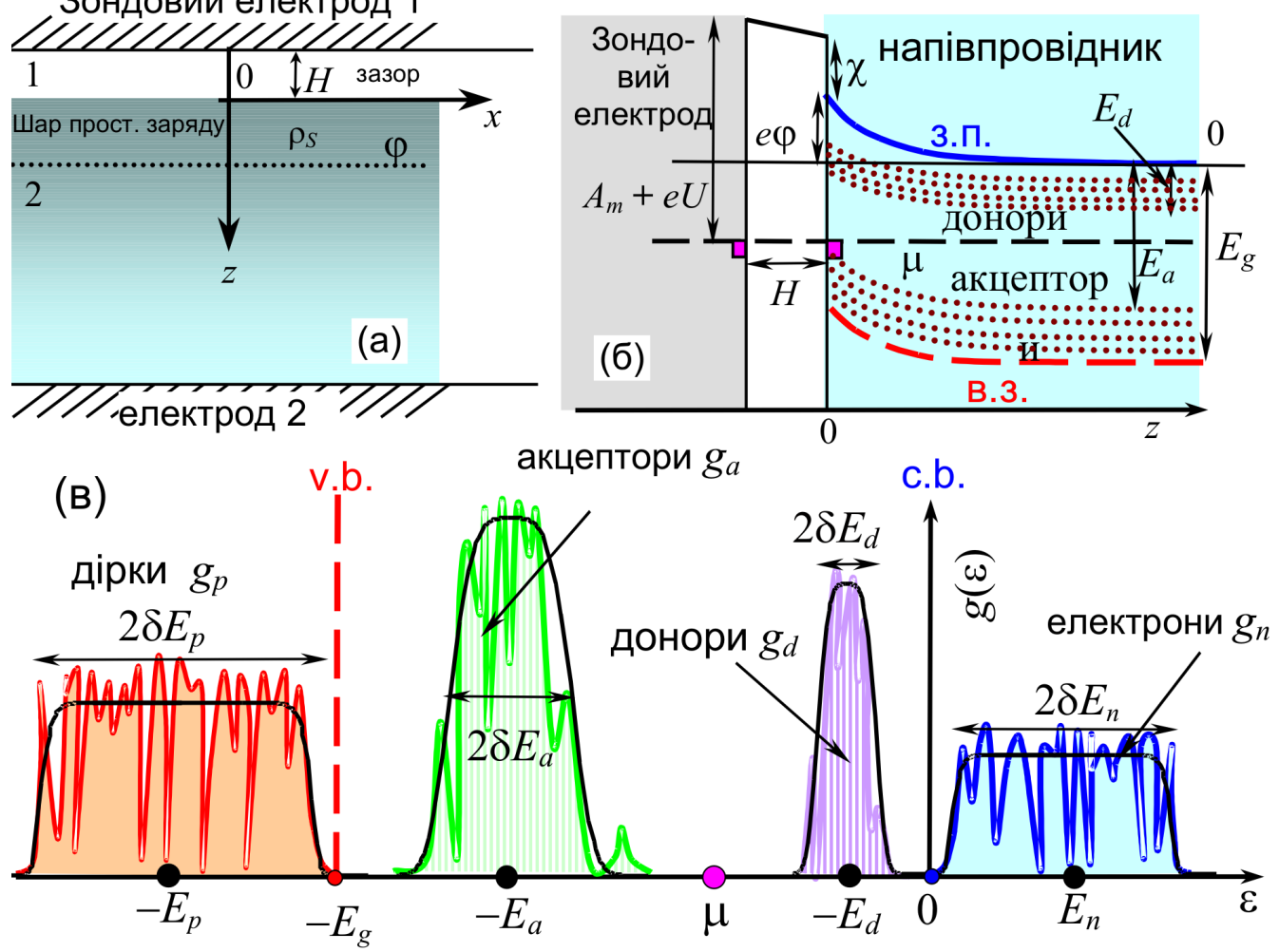

Рис. 2. Схема досліджуваної асиметричної гетероструктури “зондовий електрод/зазор/плівка іоніка-напівпровідника" ( $a$ ). Схематична зонна структура поблизу поверхні $z=0: A_{m}$ - різниця роботи виходу, $U$ - електрична напруга, що прикладається до голки зонда (верхнього електрода) при $z=-H, \varphi$ - електричний потенціал, $\chi-$ спорідненість електронів у напівпровіднику, $\mu$ рівень хімічного потенціалу (б). Локалізовані густини станів $g(\varepsilon)$ для дірок, акцепторів, донорів і електронів (в). Заповнені області з нерівними краями схематично показують типову густину станів, розраховану з теорії функціоналу густини. Експоненціальні апроксимації (2) показані плавними лініями

$$
0 \leq \rho \leq \infty
$$

але омічними для електронів (або дірок), тобто повний заряд $\rho_{S}(0, h)=0$.

Механічну деформацію плівки $u_{i j}$ розраховано з лінійного рівняння Ламе:

$$
c_{i j k l} \frac{\partial^{2} u_{k}}{\partial x_{j} \partial x_{l}}=-\frac{\partial}{\partial x_{j}} \times
$$$$
\times\left(\begin{array}{l}
-\beta_{i j}^{a}\left(N_{a}^{-}(\mathbf{r})-N_{a 0}^{-}\right)-\beta_{i j}^{d}\left(N_{d}^{+}(\mathbf{r})-N_{d 0}^{+}\right)+ \\
+\Xi_{i j}^{C}\left(n(\mathbf{r})-n_{0}\right)+\Xi_{i j}^{V}\left(p(\mathbf{r})-p_{0}\right)
\end{array}\right)
$$

$\mathrm{У}$ рівнянні (6) $c_{i j}$ - тензор пружних жорсткостей, $\beta_{i j}^{d, a}$ - тензори вегардівського розширення [25-27] для іонів (донорів, акцепторів) або вакансій. Електрони та дірки дають внесок у механічну деформацію плівки, пропорційно деформаційному потенціалу $\Xi_{i j}^{C, V}$.
Механічні крайові умови залежать від пружних властивостей підкладки та верхнього електрода (зонда або зазору). Зокрема, нормальні напруження $є$ нехтовно малими на контакті зонд/плівка та зміщення відсутнє на контакті з підкладкою:

$\sigma_{3 i}\left(x_{1}, x_{2}, z=0\right)=0, \quad u_{i}\left(x_{1}, x_{2}, z=h\right)=0$.

$\mathrm{y}$ наближенні розділення електромеханічного зв'язку відхилення $\delta N_{d}^{+}(\mathbf{r})=\left(N_{d}^{+}(\mathbf{r})-N_{d 0}^{+}\right), \delta N_{a}^{-}(\mathbf{r})=$ $\left(N_{a}^{-}(\mathbf{r})-N_{a 0}^{-}\right), \quad \delta n(\mathbf{r})=\left(n(\mathbf{r})-n_{0}\right)$ та $\delta p(\mathbf{r})=$ $\left(p(\mathbf{r})-p_{0}\right)$ концентрацій донорів $N_{d}^{+}(\mathbf{r})$, акцепторів $N_{a}^{-}(\mathbf{r})$, електронів та дірок від рівноважних концентрацій $N_{d 0}^{+}, N_{a 0}^{-}, n_{0}$ та $p_{0}$ визначаються 3 розв'язку рівнянь (1)-(4) без урахування пружної підсистеми. Так, методом функцій Гріна [12] було одержано наближений розв'язок рівняння Ламе (6):

$u_{3}(z=0, \rho, \omega) \approx \frac{1}{c_{33}} \int_{0}^{\infty} d k J_{0}(k \rho) k \times$

ISSN 2071-0194. Укр. фіз. журн. 2011. Т. 56, №11 

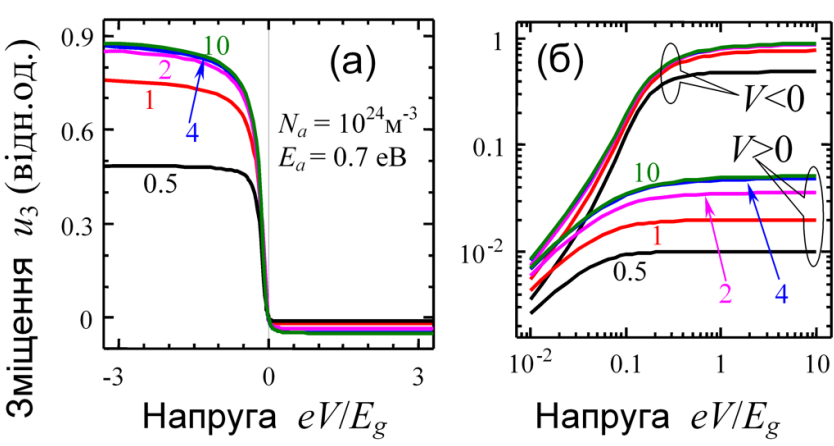

Рис. 3. Нормовані статичні механічні зміщення поверхні $u_{3}$, обчислені для різної товщини плівки $h / R_{S}=0,5,1 ; 2 ; 4 ; 10$ (див. числа біля кривих) і енергія активації акцепторів $E_{a}=$ $0,7 \mathrm{eB}$, концентрація акцепторів $N_{a}=10^{24} \mathrm{M}^{-3}$, концентрація донорів $N_{d}=10^{20} \mathrm{M}^{-3} . R_{S}$ - радіус екранування. Розрахункові параметри: $R_{S}=3,0$ нм та $\mu=-0,80 \mathrm{eB}$

$$
\times\left(\begin{array}{l}
\Xi_{33}^{C} \int_{0}^{\infty} \exp (-k z) \delta n(k, z, \omega) d z+ \\
+\Xi_{33}^{V} \int_{0}^{\infty} \exp (-k z) \delta p(k, z, \omega) d z \\
-\beta_{33}^{d} \int_{0}^{\infty} \exp (-k z) \delta N_{d}^{+}(k, z, \omega) d z- \\
-\beta_{33}^{a} \int_{0}^{\infty} \exp (-k z) \delta N_{a}^{-}(k, z, \omega) d z
\end{array}\right) .
$$

У рівнянні (8) $\delta N_{d}^{+}(k, z, \omega), \delta n(k, z, \omega)$ та фур'єспектри, $k^{2}=k_{x}^{2}+k_{y}^{2} J_{0}(x)-$ функція Бесселя нульового порядку.

3 рівняння (9) випливає, що у випадку електродів, "блокуючих" для іонів для одновимірної геометрії $(k=0)$ через збереження заряду іонів, лише зміни концентрації дірок та електронів приводять до механічного зміщення поверхні плівки від електричної напруги, прикладеної до зонда. Це зміщення безпосередньо реєструється методами С3М.

Чисельні стаціонарні розв'язки нелінійних рівнянь (1)-(8) одержано за допомогою спеціальної програми, написаної в пакеті МатЛаб.

\section{4. Результати та їх обговорення}

Статичний локальний електромеханічний відгук зображено на рис. 3. Графік (б) подібний до графіка $(a)$, але в подвійному логарифмічному масштабі. Графік зміщення є сильно асиметричним відносно зміни знака напруги ("випрямлення" електромеханічного відгуку вдвічі), що є аналогом діодного ефекту.

Динамічний локальний електромеханічний відгук, розрахований у лінійному наближенні, зображений на рис. 4. У лінійному наближенні петлі мають елі-
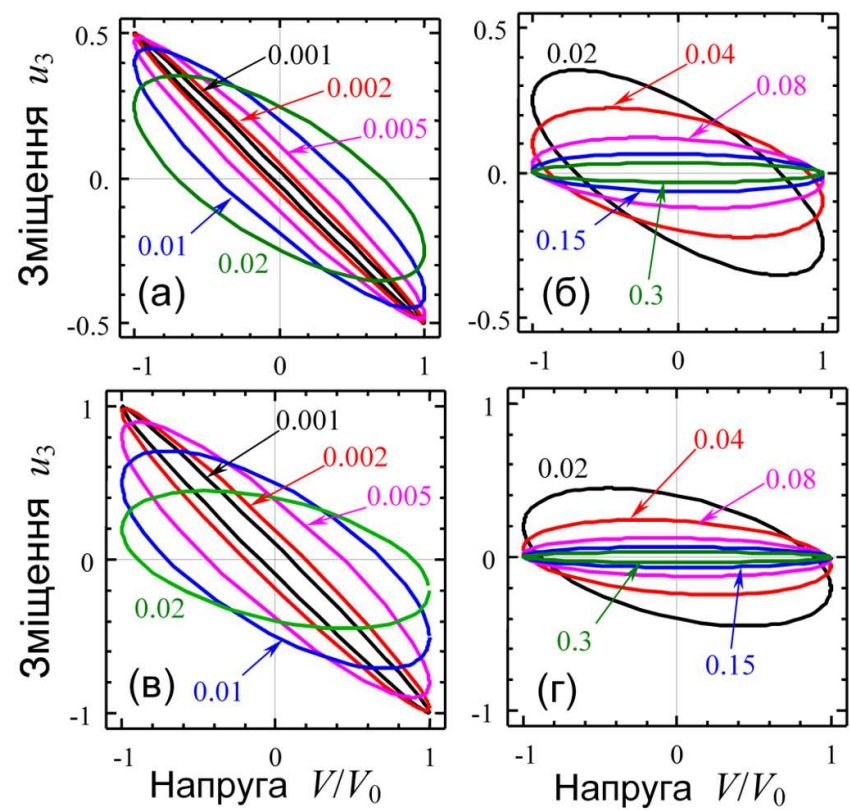

Рис. 4. Петлі гістерезису лінійного локального електромеханічного відгуку: дійсна частина зміщення поверхні $u_{3}$ від дійсної частини прикладеної напруги при різних значеннях частоти $w \tau_{M}$, обезрозміреної на час максвеллівської релаксації заряду $\tau_{M}$ (див. числа біля кривих), розраховані для зазору товщиною $\tilde{H} / R_{S}=0(a, \sigma)$ та $1(в, 2)$. Товщина плівки $h / h R_{S}=100$, крайові умови: $J_{\omega}^{c}(0)=0, \rho_{\omega}(h)=0$ (зазор на поверхні, омічний контакт з нижній електродом)

птичну форму і вироджуються у пряму лінію у статичному випадку нульової частоти. Петлі гістерезису виникають внаслідок запізнення фази носіїв по відношенню до зміни фази напруги.

Типові нелінійні динамічні деформаційновольтові петлі гістерезису в тонкій плівці іоніканапівпровідника з рухливими акцепторами і дірками показано на рис. 5, 6. Графіки $a$, в, д побудовано 3 використанням локалізованих DOS для іонів та електронів; графіки б, г, $e-$ у наближенні Больцмана.

Деякі типи гістерезису з яскраво вираженими вікнами пам'яті (шириною петлі гістерезису) і подвійною петлею спостерігаються експериментально в корельованих оксидах і матеріалах 3 резистивною пам'яттю, тоді як теоретично передбачені деформаційно-вольтові петлі гістерезису п'єзоелектричного типу, які мають метеликоподібну форму, чекають експериментального підтвердження методами зондової скануючої мікроскопії.

Зауважимо, що використовуючи незалежні вимірювання вольт-фарадних характеристик (тобто залежність повного електричного заряду від прикла- 

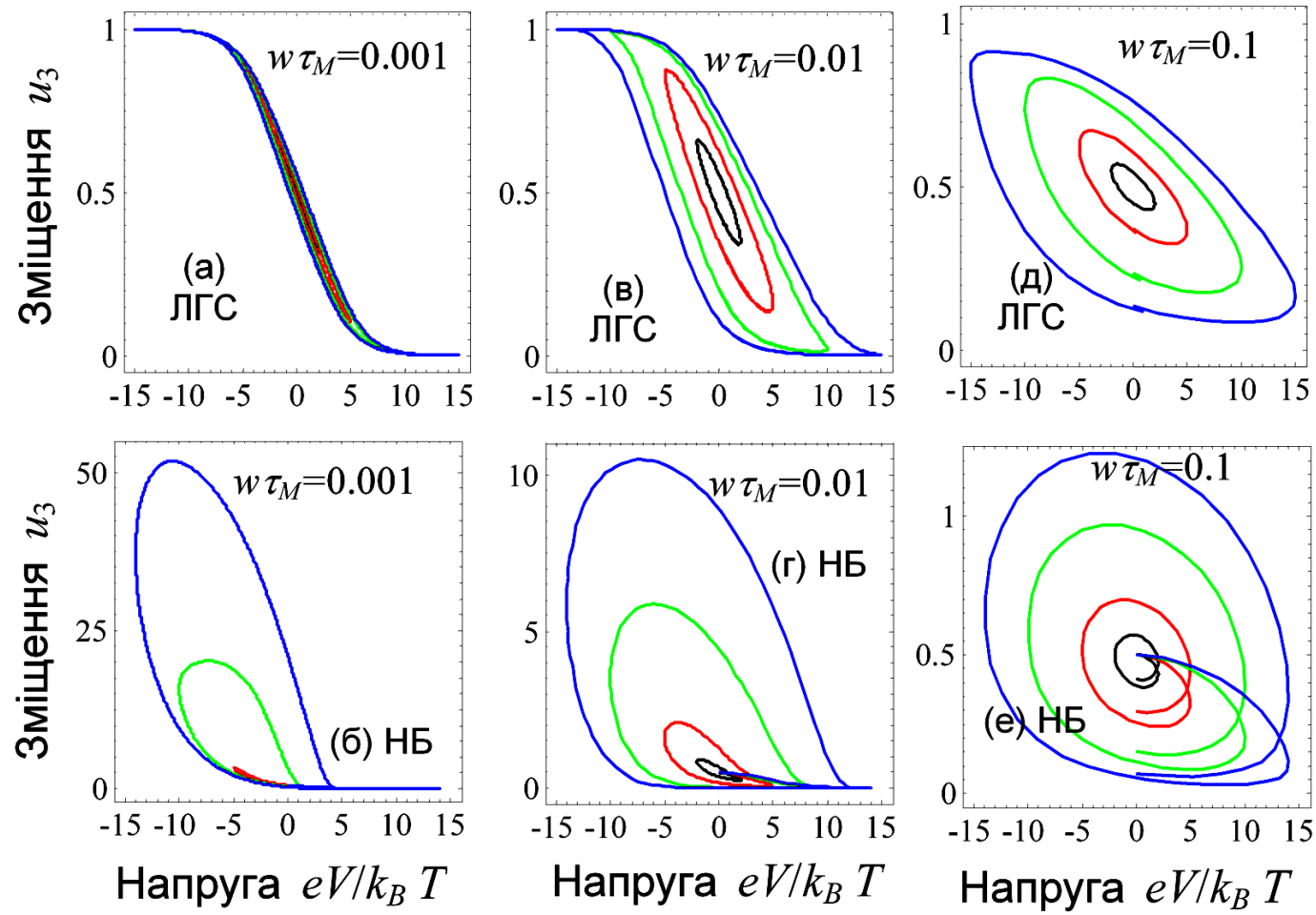

Рис. 5. Нелінійний локальний електромеханічний відгук, розрахований для різних частот: $w \tau_{M}=0,001(a, \sigma), w \tau_{M}=0,01$ $\left(\right.$ в, г) i $w \tau_{M}=0,1(\partial, e)$. Різні петлі відповідають різним значенням максимальної напруги $V=2,5,10,15$ (в одиницях $\left.k_{\mathrm{B}} T / e\right)$. Графіки $(a$, в, д) побудовані з використанням локалізованих густин стану (ЛГС); графіки (б, г, e) - у наближенні Больцмана (НБ). Параметри ЛГС: $k=4, \delta E_{a} / k_{\mathrm{B}} T=2, \delta E_{p} / k_{\mathrm{B}} T=20, N_{a}=N_{p}$; товщина плівки $h / R_{S}=5$, відношення рухливостей акцепторів до дірок $\eta_{a} / \eta_{p}=0,1$. Накладаються асиметричні крайові умови: нижній електрод є пропускаючим для дірок $\rho_{S}(h)=0$, а верхній - блокуючим $J_{c}^{p}(0)=0(\rho-$ густина заряду, $J-$ струм $)$

деної напруги), та порівнюючи їх з електромеханічними (тобто вольт-деформаційними) характеристиками можна оцінити відповідну константу деформаційного потенціалу, що не завжди добре відома. Для цього можна використовувати таке співвідношення між переміщенням поверхні плівки $\left(\delta u_{3}(z=\right.$ $0, \omega))$ компонентами тензора $\Xi_{i j}^{V}$ та концентрацією дірок $\delta p$ у плівці з рухомими акцепторами: $\delta u_{3}(z=$ $0, \omega)=\left(\frac{s_{12}\left(\Xi_{11}^{V}+\Xi_{22}^{V}\right)}{s_{11}+s_{12}}-\Xi_{33}^{V}\right) \int_{0}^{h} d z \delta p(z, \omega)$. Електромеханічний відгук плівки з рухливими іонізованими донорами і електронами може бути проаналізований аналогічним чином.

\section{5. Висновки}

Робота присвячена розрахункам статичного та динамічного локального електромеханічного відгуку тонких плівок іоніків-напівпровідників. Використовуючи добре локалізовану густину станів та наближення Больцмана проаналізовано, яким чином зміни кон- центрації іонів, дірок та електронів приводять до механічного зміщення поверхні плівки від електричної напруги, прикладеної до зонда, що безпосередньо реєструється методами СЗМ. Показано, що наближення Больцмана стає несправедливим для опису локального електромеханічного відгуку плівок зі збільшенням максимальної амплітуди напруги, і локалізована густина станів має бути використана для розрахунку квазірівнів Фермі, електричних струмів та електромеханічного відгуку.

Результати були отримані в лінійній теорії екранування Дебая (відповідні петлі гістерезису електромеханічного відгуку мають еліптичну форму) та за їі межами (нелінійне наближення). Ми отримали велику різноманітність нелінійних статичних і динамічних деформаційно-вольтових петель гістерезису в тонкій плівці іоніка-напівпровідника 3 рухливими акцепторами (донорами) і дірками (електронами).

Коли зондовий електрод і підкладка є блокуючими для іонів (акцепторів чи донорів), зміна концентрації дірок (електронів) через електрон-фононний зв'я- 

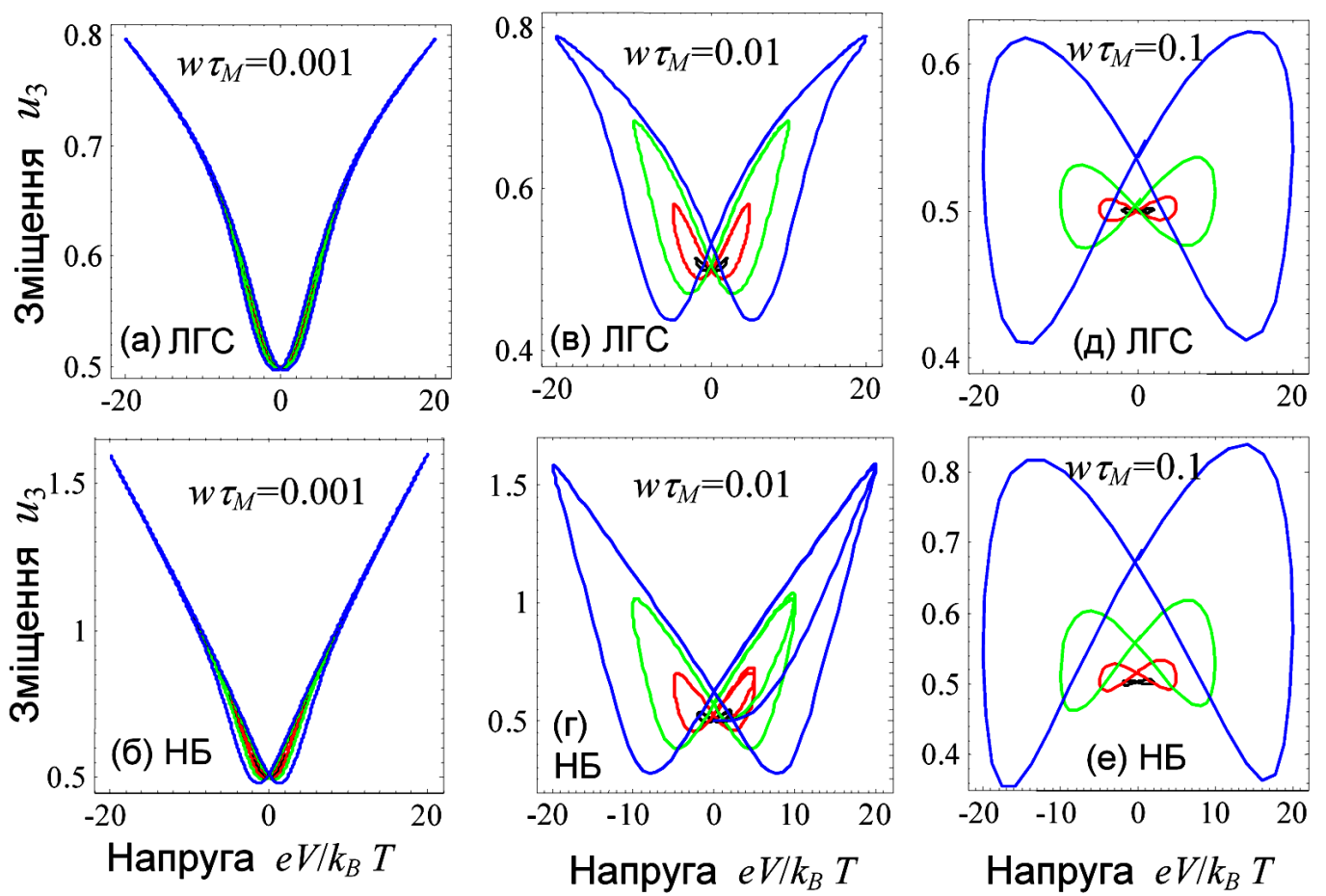

Рис. 6. Нелінійний локальний електромеханічний відгук, розрахований для різних частот: $w \tau_{M}=0,01(a, \sigma), w \tau_{M}=0,03(\varepsilon$, г) і $w \tau_{M}=0,1(\partial, e)$. Різні петлі відповідають різним значенням максимальної напруги $V_{0}=2,5,10,20$ (в одиницях $\left.k_{\mathrm{B}} T / e\right)$. Графіки $a$, в, д побудовані з використанням локалізованих густин стану; графіки 6 , г-у наближенні Больцмана. Параметри ГС $(2): k=4, \delta E_{a} / k_{\mathrm{B}} T=2, \delta E_{p} / k_{\mathrm{B}} T=20, N_{a}=N_{p}$; товщина плівки $h / R_{S}=5$, відношення рухливостей $\eta_{a} / \eta_{p}=0,1$. Накладаються симетричні крайові умови для густини зарядів $\rho_{S}(0)=\rho_{S}(h)=0$

зок приводить до механічного зсуву поверхні плівки, яка вимірюється за допомогою СЗМ. Величина зв'язку пропорційна деформаційному потенціалу, який, в свою чергу, може бути підсилений локальними деформаціями Яна-Теллера, що існують в корельованих оксидах, таких як $\mathrm{La}_{1-x} \mathrm{Sr}_{x} \mathrm{MnO}_{3} \mathrm{i}$ $\mathrm{La}_{1-x} \mathrm{Sr}_{x} \mathrm{CoO}_{3}$. Це дозволяе пов'язати електромеханічний відгук з локальним деформаційним потенціалом іоніків типу корельованих оксидів.

Таким чином, доведено, що вивчення переміщення поверхні іоніка-напівпровідника може надати важливу інформацію про локальні зміни зарядового стану акцепторів (донорів) та електрон-фононні кореляції через деформаційний потенціал.

Роботу виконано за рахунок бюджетних коштів, наданих Державним агентством 3 питань науки, інновацій та інформатизації України через Державний Фонд фундаментальних досліджень, як грант Президента України GP/F32/099.

1. Г.М. Морозовська, Г.С. Свєчніков, УФЖ Огляди 6, 140 (2010).
2. A. Sawa, Mater. Today 11, 28 (2008).

3. Y. Gil, O.M. Umurhan, and I. Riess, Solid State Ionics 178, 1 (2007).

4. Y. Gil, O. M. Umurhan, and I. Riess, J. Appl. Phys. 104, 084504 (2008).

5. M. Imada, A. Fujimori, and Y. Tokura, Rev. Mod. Phys. 70, 1040 (1998).

6. J.F. Mitchell, D.N. Argyriou, C.D. Potter, D.G. Hinks, J.D. Jorgensen, and S.D. Bader, Phys. Rev. B 54, 6172 (1996)

7. M. Vracar, A. Kuzmin, R. Merkle, J. Purans, E.A. Kotomin, J. Maier, and O. Mathon, Phys. Rev. B 76, 174107 (2007).

8. Y. Sun, S.E. Thompson, and T. Nishida, J. Appl. Phys. 101, 104503 (2007).

9. S.V. Kalinin, N. Balke, N.J. Dudney, and S. Jesse, Li-ion microscopy, patent disclosure unpublished.

10. N. Balke, S. Jesse, Y. Kim, L. Adamczyk, A. Tselev, I.N. Ivanov, N. Dudney, and S.V. Kalinin, Nano Letters 10, 3420 (2010). 
11. N. Balke, S. Jesse, A.N. Morozovska, E.A. Eliseev, D.W. Chung, Y. Kim, L. Adamczyk, R.E. Garcia, N. Dudney, and S.V. Kalinin, Nature Nanotechnology 5, 749 (2010).

12. A.N. Morozovska, E.A. Eliseev, A.K. Tagantsev, G.S. Svechnikov, Long-Qing Chen and S.V. Kalinin, (accepted to Phys. Rev. B).

13. A.N. Morozovska, E.A. Eliseev, G.S. Svechnikov, and S.V. Kalinin, http://arxiv.org/abs/1102.5526.

14. F. Ciucci, Y. Hao, and D.G. Goodwin, Phys. Chem. Chem. Phys. 11, 11243 (2009).

15. J. Svoboda and F.D. Fischer, Acta Mater. 57, 4649 (2009).

16. A.G. Tangena, J. Middelhock, and N.F. de Rooij, J. Appl. Phys. 49, 2876 (1978).

17. J.R. Macdonald, J. Chem. Phys. 58, 4982 (1973).

18. D.R. Franceschetti and J.R. Macdonald, J. Appl. Phys. 50, 291 (1979).

19. N.W. Ashcroft and N.D. Mermin, Solid State Physics (Holt, Rinehart and Winston, New York, 1976).

20. S.M. Sze, Physics of Semiconductor Devices (WileyInterscience, New York, 1981).

21. J.S. Newman, Electrochemical Systems (Prentice Hall, New Jersey, 1980).

22. J.M. Zaiman, Principles of the Theory of Solids (Cambridge University Press, London, 1969).

23. Y. Sun, S.E. Thompson, and T. Nishida, J. Appl. Phys. 101, 104503 (2007).

24. H.-Ch. Chang and G. Jaffe, J. Chem. Phys. 20, 1071 (1952).

25. F.C. Larche and J.W. Cahn, Acta Metall. 21, 1051 (1973).

26. X. Zhang, W. Shyy, and A. M. Sastry, J. Electrochem. Soc. 154, A910 (2007).

27. Y.T. Cheng and M.W. Verbrugge, J. Appl. Phys. 104, 083521 (2008).

Одержано 22.04.2011
ЛОКАЛЬНЫЙ ЭЛЕКТРОМЕХАНИЧЕСКИЙ ОТКЛИК ТОНКИХ ПЛЕНОК ПОЛУПРОВОДНИКОВ-ИОНИКОВ

А.Н. Морозовская, Г.С. Свечников, К.В. Деркач

$\mathrm{P}$ е $з$ ю м е

Проведены расчеты локального электромеханического отклика тонких пленок полупроводников-иоников, вызванного локальными изменениями концентрации ионов (стехиометрический вклад) и свободных электронов и дырок (электронфононное взаимодействие через деформационный потенциал). Получены динамические деформационно-вольтовые петли гистерезиса в тонкой пленке ионика-полупроводника с подвижными акцепторами (донорами) и дырками (электронами).

В случае "блокирующих" электродов, которые не пропускают ионы, изменения концентрации дырок (электронов) вносят основной вклад в зависимость механического смещения поверхности пленки от электрического напряжения, приложенного к зонду, которое непосредственно регистрируется методами сканирующей зондовой микроскопии (С3M). Таким образом, СЗМ перемещения поверхности ионикаполупроводника может предоставить важную информацию о локальных изменениях зарядового состояния акцепторов (доноров) и электрон-фононные корреляции через деформационный потенциал.

\section{LOCAL ELECTROMECHANICAL RESPONSE OF IONIC SEMICONDUCTOR THIN FILMS}

\section{A.N. Morozovska, G.S. Svechnikov, K.V. Derkach}

V. Lashkaryov Institute of Semiconductor Physics, Nat. Acad. of Sci. of Ukraine

(41, Prosp. Nauky, Kyiv 03680, Ukraine)

S u m m a r y

We report on the calculations of a local electromechanical response of ionic semiconductor thin films induced by local changes of the concentration of ions (stoichiometric contribution) and free electrons and holes (electron-phonon interaction via the deformation potential). Dynamic strain-voltage hysteresis loops are obtained for an ionic semiconductor thin film with mobile acceptors (donors) and holes (electrons).

In case of ion-blocking electrodes, changes in the hole (electron) concentration make a dominant contribution to the dependence of the mechanical displacement of the film surface on the voltage applied to the probe, which is directly registered by scanning probe microscopy (SPM) methods. Thus, the displacement of the ionic semiconductor surface can provide an important information on local changes of the charge state of acceptors (donors) and electron-phonon correlations via the deformation potential. 